\title{
Valuing the IJTMB Manuscript Review Board
}

\author{
Antony J. Porcino, BSc, PhD (candidate)
}

\section{Complementary Medicine Education and Outcomes Research Program, British Columbia Cancer Agency, Vancouver, BC, Canada}

The honor of becoming Executive Editor of the IJTMB affords me increased appreciation for the process of research publishing. While authors work arduously to produce strong research and reporting, the Editorial Board, comprising six volunteers (http:// www.ijtmb.org/index.php/ijtmb/about/editorialTeam) and a great team of support persons, works painstakingly to ensure quality research articles live in the IJTMB. As a critical part of producing each journal issue, the Editorial Board coordinates the Journal's network of volunteer reviewers, the Manuscript Review Board (MRB). I'd like to present and thank the IJTMB MRB reviewers* of the past three years:

Katie Adams
Derek Austin
John Balletto
Amanda Baskwill
Peter Becker
Susan Bessonette
Karen Boulanger
Anne Brodie
Marissa Brooks
Celia Bucci
Elaine Calenda
Jerrilyn Cambron
Susan Chapelle
Rosemary Chunco
Laurie Craig
Michael Donnelly
Edward Feinberg
Paul Finch
Thomas Findley
Pamela Fitch
Cathy Fournier
Sandy Fritz
Kimberly Goral
Donelda Gowan-Moody
Keith Grant
Michael Hamm
Bodhi Haraldsson
Kate Henrioulle
Sandra Hilton

Glenn Hymel
Colby Inzer
Steve Jurch
Janet Kahn
Ania Kania
Ronald Kettering
Kim Lemoon
Whitney Lowe
Martha Menard
Lisa Mertz
Albert Moraska
Christopher Moyer
Sonya Munk
Armijo Olivo
Darlene Peters
Grant Rich
Melody Rudolph
Joellen Sefton
Marybetts Sinclair
Matthew Stewart
Tim Tanaka
Lesley Teitelbaum
Robin Thomas
Diana Thompson
Ravensara Travillian
Charlotte Versagi
Ruth Werner
Pete Whitridge

*(with apologies and requests for overlooked names)
The work of reviewers is the lifeblood of an effective and rigorous peer-reviewed journal. Personal time spent and dedication are the cornerstones. Each submitted article must receive written reviews from at least two reviewers. The reviewers read each article several times, make notes on their observations about the background they are supplied within the article, and consider the research approach and methods, including whether those are appropriate to the question(s) and objectives being addressed in the article. They carefully review the results, how they were achieved, interpreted, and presented. Finally, they analyze the discussion to consider whether it pulls everything together and whether the objectives of the project were actually achieved. They also examine whether the writing is helping or hindering the reading of the article. They then write a response, drawing on what they have observed and on their own expertise, in order to create a review that carefully, but helpfully, leads the author(s) to creating a successful journal article.

Becoming the Executive Editor has emphasized for me the importance of the peer review process. With all the options now possible for self-publication and promotion, some argue that it isn't important, at least in its current form ${ }^{(1)}$. Additionally, Internet publishing offers many ways of circumventing peer review or reducing its effectiveness ${ }^{(2)}$, yet the soundness of quality, ethical peer review remains important in today's electronic media society ${ }^{(3)}$. IJTMB's peer review ensures appropriateness and rigor in the research that establishes the future of our therapeutic massage and bodywork professions. As a peer-reviewed journal in a young field of research, the IJTMB has a careful balancing act if it is not to overly burden its reviewers. Issues include: (a) the pool of experienced research persons to draw on to create its MRB is still growing; (b) specific areas of researcher expertise and knowledge may be very limited because the actual methods of researching in therapeutic massage and bodywork are still being refined; (c) and many researchers, authors, and peer reviewers may not have much publication or peer-review experience. Each of these concerns carries its own area of work for the Editorial Board. I will work over the next few 
years to expand our MRB and increase our education for reviewers, in order to maintain quality and rigor in the articles that the IJTMB publishes. I am grateful, and I am sure the readers are grateful, for those who have worked to help our body of knowledge grow, and for the many people developing research expertise in their fields of therapeutic massage and bodywork service.

The development of the IJTMB MRB has been organic, and has drawn interest from many great colleagues and researchers internationally within the therapeutic massage and bodywork field. With three years under its publication belt, we're ready to start tweaking some processes for the Journal so that we can serve authors and readers even better. The Editorial Board will be reviewing the MRB development process this summer.

I would like to encourage more people to consider being a peer-reviewer for the Journal. If you are interested and would like to be contacted, please send me an email.

Finally, my hat is off to the several journal editors below, who have inspired me with their recent editorials on peer review:

- Rita Redberg, (Redberg R. Annual Reviewers List. Archives of Internal Medicine. 2012;172(6): 458-460)

- Roger Watson (Watson R. Peer review under the spotlight in the UK. Journal of Advanced Nursing. 2012;68(4):718-720)

- Leon Chaitow (Chaitow L. Recognizing reviewers. Journal of Bodywork and Movement Therapies. 2012;16(1):1)
And yes, this editorial was also peer-reviewed.

Antony J. Porcino, $\mathrm{BSc}, \mathrm{PhD}$ (candidate) Executive Editor, IJTMB

\section{CONFLICT OF INTEREST NOTIFICATION}

The author declares there are no conflicts of interest.

\section{COPYRIGHT}

Published under the CreativeCommons AttributionNonCommercial-NoDerivs 3.0 License.

\section{REFERENCES}

1 The Editors. Rethinking Peer Review. The New Atlantis. 2006;13(Summer):106-110. Available from: http://www. thenewatlantis.com/publications/rethinking-peer-review. Accessed May 30, 2012.

2 Stratford M. 'Predatory' Online Journals Lure Scholars Who Are Eager to Publish. The Chronicle of Higher Education. Published March 4, 2012. http://chronicle.com/article/PredatoryOnline-Journals/131047/. Accessed March 8, 2012.

3 Science and Technology Committee, House of Commons. Peer Review in Scientific Publications. Report HC 856. London, UK: The Stationary Office; 2011. p.254. Available from: http:/www.publications.parliament.uk/ $\mathrm{pa} / \mathrm{cm} 201012 / \mathrm{cmselect} / \mathrm{cmsctech} / 856 / 856$.pdf. Accessed March 8, 2012. 